\title{
FOLKLORE CONFERENCE IN UKRAINE
}

Natalie Kononenko, University of Virginia

The Kyiv based Center for the Study of Oral History and Culture, the journal Rodovid, and the Cherkasy Ethnographic Museum invite you to take part in an international conference in Cherkasy, Ukraine as well as to conduct fieldwork (if you so wish) in central Ukraine in August 1998.

The conference is "Problems in Oral History Research on East European Villages of the 1920's1940's." It will take place August 4-7, 1998 in the Cherkasy Ethnographic Museum. An optional additional activity is to conduct fieldwork in villages under the guidance of local ethnographers of the Center and the Museum. Field trips begin August 8, the duration of the fieldwork is up to the scholar and can continue for as many days as you wish. Both the conference and the fieldwork opportunity are geared to be of interest to ethnographers of all stripes (anthropologists, ethnomusicologists, sociologists) as well as to folklorists and historians.

One of the most serious lacunae in Soviet era ethnography is oral history: not only its collection but its interpretation as well. What few oral history projects were undertaken were seriously flawed by the ideological distortions of the time. This was particularly true during the time period in question when Stalinism made any but the blandest research project impossible. From the 1950's to the 1980's little of lasting interest was accomplished in this area, and only in the last few years has competent research been undertaken. Thousands of now elderly victims/participants still live in village Ukraine who can speak to the specifics of this time period. Whatever your area of specialization, if you have an 
Interest in the collection and interpretation of oral history, or if you have experience in oral history/ ethnography that touches on the problems of this time period, we hope that you will consider joining us in August. This includes those who have conducted research in other parts of Eastern Europe and can offer a comparative view to research undertaken in Ukraine. This is, among other things, an opportunity for you to conduct comparative research in village Ukraine.

Conference Schedule

The conference languages are Ukrainian and English. Papers should be no more than twenty (20) minutes in length, with ten minutes for questions and answers immediately after each presentation. Interpreters will be available at the conference and you may read your paper in English. In such a case we request your English text in advance (by July 1) in order to assist the interpreter. Such papers will be allowed up to fifteen minutes extra (i.e., thirty-five minutes for your paper with ten minutes for questions).

You should send a one page double-spaced abstract of your paper (either English or Ukrainian) to us along with your application and registration payment. Please send to the USA Rodovid address shown below. The abstracts will be published in the conference prograrn and will be available before the conference begins. Selected papers will later be published in Ukrainian in the journal Rodovid.

The general conference schedule follows below. A more detailed schedule will be available by July 1 .

August 4 Tuesday arrival in Kyiv; transportation by car to Cherkasy free of charge 
August 5 Wednesdayplenary sessions, morning and afternoon

August 6 Thursday separate sessions, panels on:

a) changes in social structure and civil society of the time

b) transformations in expressive culture

c) repression of ethnographers and cultural activists

August 7 Friday plenary session (morning) and excursion (afternoon)

August 8 Saturday transportation from Cherkasy to Kyiv (free of charge)

or begin fieldwork project

If you wish to remain in Kyiv a longer time, we can assist you in finding accommodations.

Accommodations in Cherkasy

Hotel accommodations cost from $\$ 45$ to $\$ 90$ per night (the former for a double, the latter for a single room). Alternatively we can place you in a private apartment for $\$ 20$ a night (one or two persons to an apartment: most apartments have only one bed). One other option is to live with an English speaking family for $\$ 20$ a night per person. For no additional fee we will pick you up at the Boryspil' airport in Kyiv and transport you to Cherkasy, and later back to the airport.

Fieldwork Option

For those wishing to stay on and conduct fieldwork, this option can begin the day after the conference -- Saturday August 8 -- and last as many 
days as you wish. It costs $\$ 30$ per day, inclusive of all transportation, all meals, housing, and an accompanying ethnographer from the Center or from the Museum. if you require an interpreter the cost is an additional $\$ 10$ per day. The accompanying ethnographer will take you to representative villages in Cherkasy Oblast'. Those intending to conduct fieldwork should contact us with details as to your research interests at least by July 1 (but the earlier the better) in order for us to plan an itinerary for you. We have a wide range of specialists who work in either or both the Center and the Museum and we can accommodate most research requests.

Application: Registration Fee and Registration Form Registration fee is $\$ 90$ (USD only please). Please complete a registration form and mail it with your one page abstract and your registration fee of $\$ 90$ to the USA address inmmediately below. We need to receive your application no later than July 10,1998 in order to process it in due time. Please make checks or money orders payable to "Rodovid," and send to:

Rodovid

18200 5. Mullen Road

Belton, MO 64012 USA

\section{Other Fees and Payments}

All other fees and charges for accommodations, etc. should be paid in cash on-site in Ukraine (preferably either Ukrainian hryvnia, US or Canadian dollars, or DM). We cannot accept in Ukraine travelers checks, money orders, personal checks, or credit cards. 


\section{Visa Requirements}

Citizens of all states outside of Eastern Europe are required to have a visa to enter Ukraine. We can furnish you with a letter of invitation which you will need to acquire a visa. Because visas can take up to two weeks to be processed, we must have your request for the visa and your payment of the registration fee no later than July 10, 1998. Upon payment we will send you a letter of invitation. Please contact the Ukrainian Embassy in your country for details on visa applications.

If you have any questions, please contact either William Noll of the Center or Lidia Lykhach of Rodovid in Kyiv at tel.Ifax (+380-44) 295-4064 during normal office hours, or send a fax at any time. Or you may contact us by E-mail:

pito@gonchar.freenet.kiev.ua

We look forvard to hearing from you soon, and seeing you in Kyiv and Cherkasy in August.

\section{Sincerely,}

William Noll, Director, Center for the Study of Oral History and Culture

Lidia Lykhach, Director, Rodovid Mykola Kornienko, Research Director, Cherkasy Ethnographic Museum

(The Registration Form is not included in this message. Please contact Natalie Kononenko at nkm@virginia.edu, or Rodovid at the Belton, MO address.) 